\title{
Editorial $^{*}$
}

A Revista Serviço Social \& Sociedade traz neste número relevantes contribuições para o desvendamento crítico dos processos de trabalho e das respostas públicas no âmbito da crise do capital.

São apresentados três importantes artigos — dos professores José Paulo Netto, Josiane Soares Santos e Marcelo Braz - expostos na mesa de abertura do $5^{\circ}$ Seminário Anual de Serviço Social: Crise do capital, particularidades da questão social no Brasil e a organização dos trabalhadores em seu estágio atual, promovido pela Cortez Editora, em comemoração ao dia do assistente social. Esses artigos destacam o complexo e contraditório cenário do capitalismo contemporâneo e suas crises, as particularidades da formação social brasileira e o modo como se expressa a "questão social" no Brasil, bem como as polêmicas para compreender as lutas de classes contemporâneas.

Esses temas, a partir de distintas abordagens, são também tratados em outros seis artigos, nos quais são discutidas particularidades da questão social e as contradições expressas pelas respostas do Estado a questões como: acolhimento familiar e as leis protetivas; política de emprego no Brasil no contexto da flexibilização de direitos e relações de trabalho; desemprego, precarização e informalidade do trabalho dos negros no Brasil; relações de gênero no trabalho da agroindústria; a judicialização do benefício de prestação continuada da política de assistência social e o campo de trabalho profissional nos governos municipais.

Nesse mesmo contexto da crise, considerando os questionamentos ao modelo de desenvolvimento e as novas demandas da sociedade civil organizada, apresentamos também um artigo que problematiza a produção de indicadores sociais alternativos e as exigências de novas formas de quantificação diante do aprofundamento das desigualdades sociais em dimensão global.

Completa este número a resenha do livro de Marcelo Braz, Partido e Revolução - 1848-1989, destacando-se a contribuição do autor para "a revitalização teórica e política da possibilidade de revolução como emancipação humana”.

* Por ocasião do fechamento deste número, recebemos a notícia do falecimento do professor Aloísio Teixeira, a quem prestamos nossa homenagem por meio do texto do professor José Paulo Netto. (N.E.) 
Finalizando este editorial, prestamos homenagem à assistente social Egli Muniz, que faleceu dia 23/6/2012, vítima de um aneurisma cerebral. Egli era professora titular da Instituição Toledo de Ensino (Bauru) e foi Secretária Municipal de Assistência Social da Prefeitura de Bauru na gestão 2005-2008. A Cortez Editora publicou sua tese de doutorado, com o título Serviços de Proteção Social: um estudo comparado Brasil-Portugal. Atuou também como consultora especialista da Secretaria Nacional de Assistência Social do Ministério de Desenvolvimento Social e Combate à Fome-MDS. Comprometida com a formação e o exercício profissional, Egli foi uma pessoa com grande capacidade de trabalho, elegante e gentil em suas relações pessoais e profissionais, que nos deixa saudades. 